\title{
Using campus concerns about sustainability as an educational opportunity: A case study in architectural design
}

Dr Elizabeth Karol

Curtin University of Technology, Perth, Western Australia

Tel 9266 7260; Fax 92662711

e.karol@curtin.edu.au 


\begin{abstract}
Curtin Environment Awareness Team (CEAT) is a group of volunteers at Curtin University of Technology in Perth, Western Australia who work together to promote awareness, activities and information dissemination related to sustainable use of the University campus. In 2003 an attempt was made to integrate a CEAT concern relating to a declining habitat for bird and animal life around a campus lake, with an undergraduate problem-based design project in the School of Architecture. After the students' work was completed, CEAT reviewed the projects and selected three schemes for possible inclusion in the program of capital works for the campus. CEAT members and students were surveyed after the design project was completed. The survey results indicated that CEAT members considered that student involvement enhanced the quality, scope and likely implementation of the project. The student survey results indicated that this project raised their awareness of the complexity of addressing sustainable use of the campus and identified the potential influence of architect designed projects on the natural environment. However in spite of formal acknowledgement of the value of the project by the Vice Chancellor of the University, there was no indication that the University plans to move from the current $a d$ hoc approach towards sustainability either in the management of the campus or in the core teaching programs.
\end{abstract}

Key words: sustainability, student projects, university education

\title{
Background - Curtin University context
}

In 1992 Curtin University of Technology (CUT) established the Curtin Environment Committee. This Committee was charged with the responsibility for coordinating activities that would enhance CUT's reputation in the field of environmental management (CUT, 1993). Very broad terms of reference were adopted for that Committee. These terms of reference included recommending action related to environmental issues on campus as well as encouraging greater environmental awareness in the wider community and in Curtin's teaching and research programs. In 1994, one of the values explicitly expressed by CUT was a commitment to promote ethical practice, social justice and environmental responsibility (CUT, 1994).

However in recent years the Curtin Environment Committee has become ineffectual. This is the result of a number of CUT management and governance decisions. One such decision was to remove financial support from the Environment Committee. Financial support was initially provided to the Environment Committee through the employment of a qualified environmental officer. However when the environmental officer left CUT in 1999 he was not replaced. Instead, an engineer from the University's Properties Office was placed in that role. Another decision, in 2000, was to remove a reference to sustainability in the CUT vision, mission and values statements (CUT 2003). A third decision was to down grade the position of the convenor of the Committee from Executive General Manager of the University to the Director of work relations. These actions conflict with the message portrayed at the CUT web site (http://www.envirolink.curtin.edu.au/index.html\#intro). This web site implies that CUT supports an active Environment Committee. As indicated by 
Carpenter and Meehan (2002) in their investigation of the position of environmental management in the business activities of Australasian universities, policies espoused by universities in relation to environmental programs are frequently peripheral and are not identified as having a significant role in the main business of the university. This is the situation at CUT.

The change in the official values statement of CUT in 2000 may have had a negative impact on undergraduate teaching programs. In support of the values expressed in the 1990s, the School of Architecture, Construction and Planning established, in 1997, an undergraduate unit entitled 'Ecologically Sustainable Design'. This unit was compulsory for all first year students in the School. Although this unit is still compulsory for architecture students, there has been no systematic progress towards extending study units related to sustainable development into all discipline areas ${ }^{i}$. Also there has been no policy decision in the School of Architecture to engender the incorporation of sustainability matters into the teaching of the major unit in the course, architectural design. Consequently a significant proportion of the actual design projects produced by architecture students during their five years in the School still ignore the question of sustainability of the built environment.

To side step the recent administrative and governance inertia surrounding the University Environment Committee, a small group of volunteers, including administrative and academic staff and student representatives, merged in 2001 to form the Curtin Environment Awareness Team (CEAT). CEAT's primary activity was to implement projects on the campus that were related to Curtin University's Cleaner Production Action Plan ${ }^{\text {ii }}$. Due to the interests of the volunteers, CEAT has moved beyond the projects in the Cleaner Production Action Plan and has raised awareness and encouraged participation in additional projects such as water awareness, campus clean up, tree planting and reducing car dependency.

It is acknowledged that CEAT is just one of the grass roots initiatives at CUT that takes in some aspects of 'sustainable living', a concept referred to by Leal Filho (2000) when exploring the meaning of the term 'sustainable development'. At CUT grass roots examples of addressing sustainability are most abundant in terms of academic research and development. Across a wide range of disciplines, CUT researchers have been successful in attracting dedicated research funding for environment and sustainability inspired applied research in areas as diverse as sustainable tourism, integration of renewable energy sources, sustainable minerals processing and greenhouse gas sequestration technologies.

\section{Background - Case study}

One project that CEAT started to consider in 2002 was the declining habitat for bird and animal life around a lake on campus. Although the lake is man-made (having been created in the 1950s with surplus clay soil from a nearby development project) the design project did not require students to assess the long-term sustainability of the lake. This was a pragmatic decision made in the context of an administration that is adamant that the lake must remain. A view of the lake, as seen from the primary administration forecourt, is shown in Figure 1. 


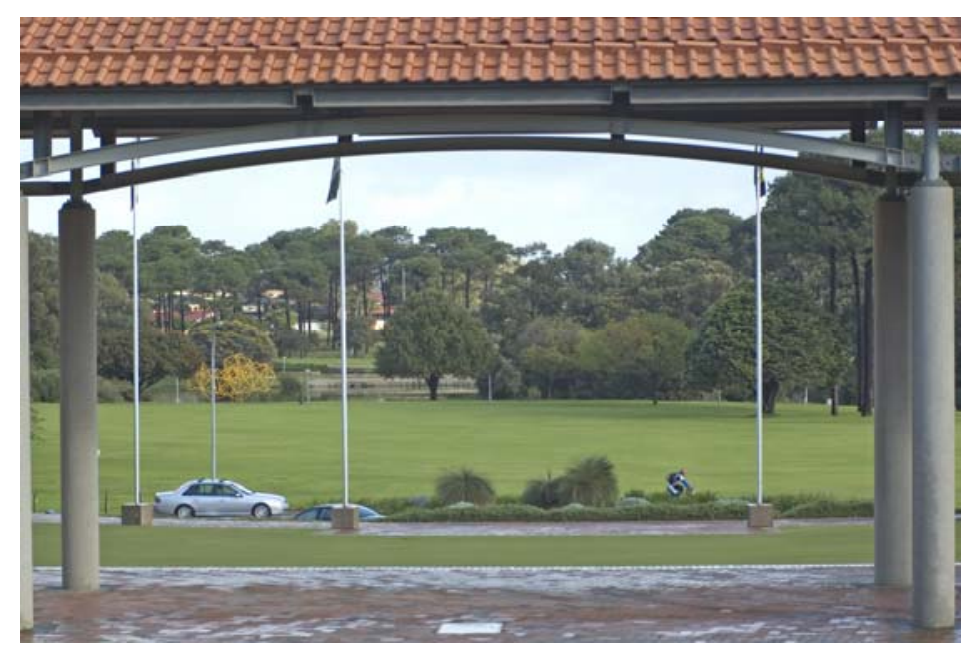

Figure $1 \quad$ View of the lake (seen in the middle distance) from primary administration forecourt

Initially CEAT looked at the degraded lake habitat for frogs and turtles resulting from the invasion of exotic plants species and poorly managed recreation uses around the lake that were affecting water quality. However it was recognised that there was potential to extend this project to incorporate additional aspects of sustainable living on the campus. For example, it could become an exemplar for the community of an urban wetland that was an educational resource, a relaxation hub and a healthy environment for native flora and fauna. This idea of an exemplar was developed in 2003 by a lecturer who was preparing an elective unit for the fourth-year architecture study program in the School of Architecture. That unit adopted a problem-based learning approach.

Problem-based learning is an accepted mode of study in professional education as it provides a method that will assist students not only to research and resolve a particular problem but also to develop a set of problem-solving competencies. These general competencies include making reasoned decisions in unfamiliar situations, adapting to change, adopting a holistic approach to problem solving and collaborating and empathising with colleagues (Engel, 1997). Problem-based learning has always formed part of architectural education in the design studio (Maitland, 1997). However the design studio is traditionally supported by formal lectures and tutorials in narrow discipline fields such as structures, architectural history and building science. As noted by Leal Filho (2000) matters related to sustainability do not fit neatly into a particular discipline so either they tend to be ignored or are taken up in an ad hoc manner depending on the interest of the staff member.

As this staff member was committed to including sustainability in teaching, the problem in the elective unit was expressed as a design brief where the environmental sustainability of flora and fauna at the lake was as important as the needs of people using the precinct. In addition, any design solution needed to be economically viable. Including sustainability in the teaching program in this way is recognized as a key means of exposing students to the sustainability agenda. As mentioned by Davis et al. (2003) in their examination of the way two American post-secondary institutions incorporate concepts of sustainability into teaching, students confirmed that their 
understanding of sustainability comes primarily through the formal classes they attend.

The lake project adopted a triple bottom line approach to design in that students were required to take into account the natural environmental, social acceptability and economic implications of their proposal. Social acceptability included examining the history of the lake, understanding the potential to develop the lake into a show case project that highlighted the fragility of the Australian landscape, making a beautiful environment for learning about local flora and fauna and establishing a delightful relaxation place for staff, students and the community. The economic implications referred to a requirement that students gain an understanding of capital costs and maintenance costs of such projects. Thus, the aspirations of CEAT regarding the environmental health of the lake could be intertwined with developing student knowledge of sustainability whilst preparing an architectural design scheme.

\section{Method}

Eighteen students enrolled for the elective unit. The study program was established as a design competition with CEAT offering prizes to three students who could most successfully produce ideas to assist in the development of the lake precinct. The design competition brief called for innovative ways of enhancing accessibility to the lake by people on campus and from the surrounding communities. At the same time the habitat for native birds, turtles and frogs was to be improved. Gathering points for educational walks and passive recreation around the lake were also required by the brief and key parts of the proposal were required to be specified to a standard that would enable quotations to be obtained for construction. Consideration was also to be given to the sustainability and maintenance requirements of the specified materials.

Two stages were defined in the study program. The first stage required that students work in small groups to collate resource material related to the project. Each group researched a different topic. Topics included a review of existing local wetland rejuvenation projects, site information (such as an analysis of water flow through the lake) and specific construction information (ranging from recycled materials suitable for outdoor use to rubbish bins that were 'bird proof'). During this stage, students were encouraged to consult with experts in their field of research. To provide further support, two consultants presented lectures on the flora and fauna of the lake. One consultant was from the School of Environmental Biology and the other one was the Curator of the University Grounds. The second stage of the program required that students examine the collated material and, individually, design an enhanced precinct around the lake. At the end of the program all students exhibited their work at a public venue on campus.

Each design proposal was assessed by the lecturer in accordance with the following four criteria:

- Evidence of resolution of student's defined design intent;

- Evidence of resolution of conflict between constructed elements, the natural environment and economic viability;

- Originality of thought;

- Clarity and appropriateness of documentation. 
At the conclusion of the study program, the six projects that were deemed to have most successfully fulfilled the design requirements were presented to a judging panel consisting of four members of CEAT together with a representative of the General Manager of University Properties Office ${ }^{\text {iii }}$. This panel assessed the projects taking into account seven factors that reflected the particular interests of panel members. It is noted that this list of factors was established after the academic study program had been completed. The assessment factors are listed below.

- Balance between recreation needs and the eco-system of the lake;

- Practicality of the proposal;

- Appropriateness of materials;

- Level of maintenance foreseen;

- Consideration of method of signage;

- Consideration of human facilities;

- Delight $^{\mathrm{iv}}$ of the scheme.

After both the academic and CEAT assessments of the projects had been completed, a survey of CEAT members and students was carried out. CEAT members were asked about the effectiveness of student involvement in this project and with CEAT projects in general. Students were asked about the relevance of the lake project to their development as architects as well as to their understanding of the campus environment.

The five questions emailed to CEAT members were:

1. Before students became involved, CEAT had a draft 3 year plan for the rehabilitation of Jack Finney lake. In what ways do you consider that plan benefited from student involvement?

2. Do you consider the process for student involvement in the Jack Finney lake design was satisfactory? If not, what was the greatest weakness?

3. How could the process of general student involvement in CEAT projects be improved?

4. What do you consider are the general benefits of involving students in CEAT projects?

5. What do you consider are general disadvantages of involving students in CEAT projects?

Participating students were emailed a different set of questions as listed below. Unfortunately, after academic assessment of the unit had been completed, the majority of students showed no interest in completing the questionnaire.

1. What did you hope to learn from the Curtin lakes rejuvenation project?

2. What were your feelings about the relevance of the project to you as a future architect?

3. What were your feelings about the relevance of the project to you as a person using the Curtin campus?

4. What do you see as the advantages of working on projects that are to be implemented on the campus?

5. What do you see as the disadvantages of working on projects on the campus? 
6. How did your perception of architect designed projects on campus influence your design around the lake?

\section{Results}

Two sets of results are presented in this paper. The first set of results considers the design resolutions and the second set of results summarise the questionnaire responses from CEAT members and students (Tables 1 and 2 respectively).

Extracts from two of the most successful schemes are shown in Figures 2 and 3. Both examples identify points of interest in the landscape where the designer provides opportunities for people to access sensitive areas without damaging the points of interest. 'Nodal Intervention' (Figure 2) emphasises the points of access and discharge of water from the lake and creates observation and resting platforms at these water points. The scheme 'Interlude' (Figure 3) places more emphasis on people moving along elevated walkways over water and through a tree canopy thus leaving the ground level less disturbed. In both these cases the capital costs and maintenance costs of materials were considered.

The less successful schemes were not able to show a cohesive idea that recognized, and to some degree resolved, the conflicting needs of people wanting to come close to the water while exercising or just relaxing and the need to provide protected habitats for birds and animals. The least successful schemes, if implemented, would not help to rejuvenate the lake precinct at all. For example one scheme provided a large interpretation platform in the area highlighted as a desirable breeding area for turtles and an enclosed activity building in a heavily treed part of the site.

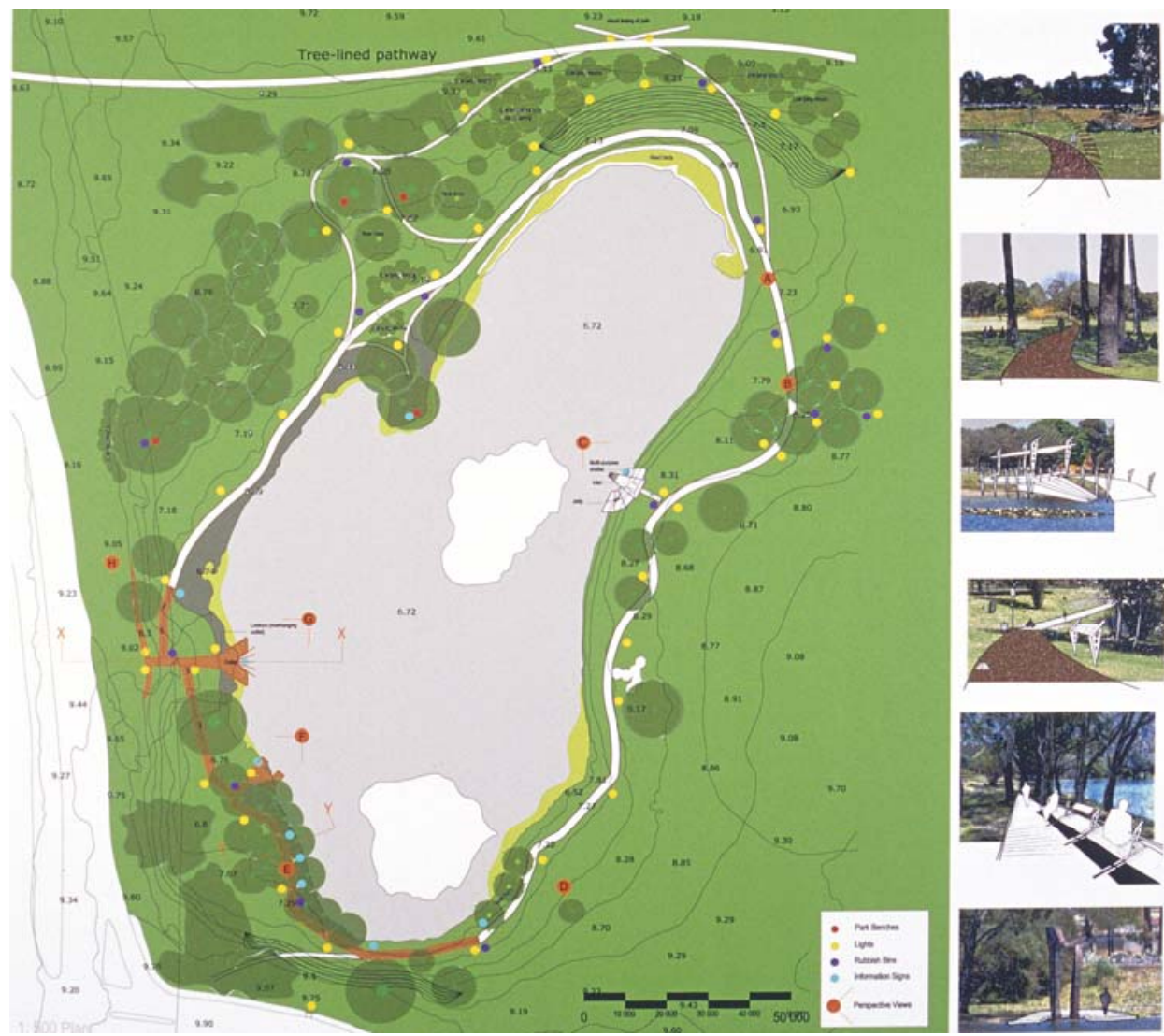


Figure 2 Student project entitled 'Nodal intervention'.
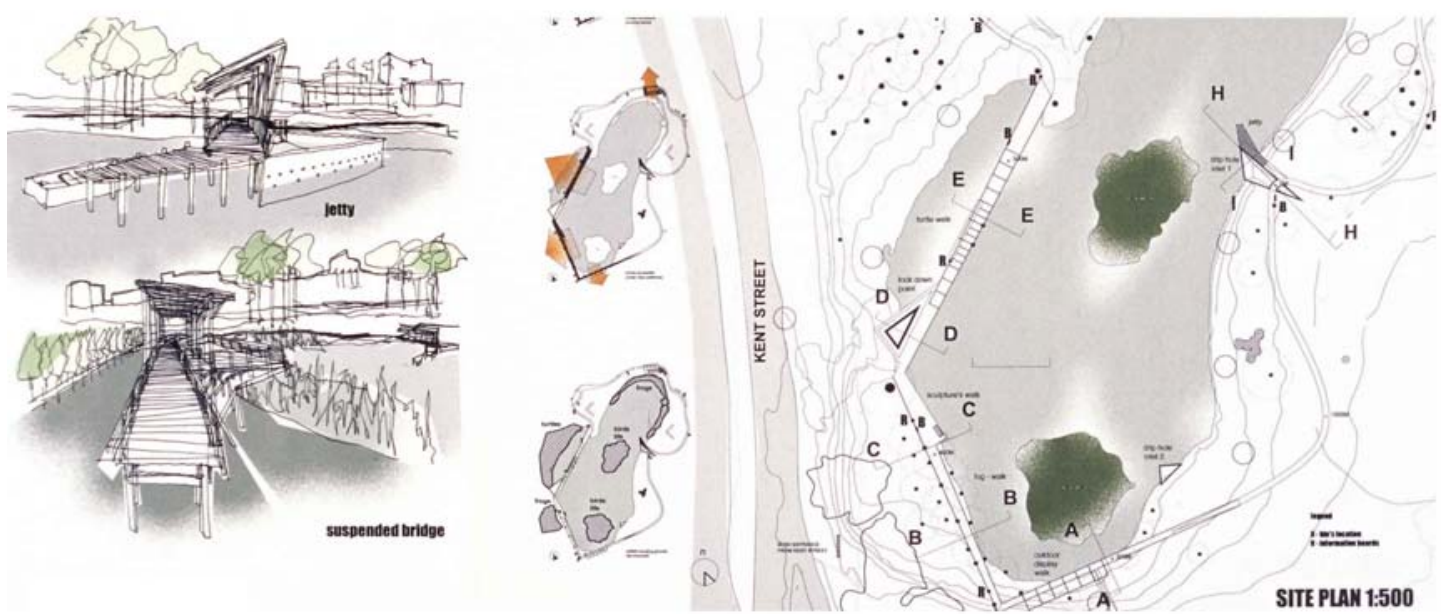

Figure 3 Student project entitled 'Interlude'.

Sixty percent of CEAT members involved in the project responded to the questionnaire. The questions and responses are summarised in Table 1 below.

\begin{tabular}{|c|c|}
\hline QUESTION & SUMMARY OF RESPONSES \\
\hline $\begin{array}{l}\text { In what ways did this } \\
\text { CEAT project benefit } \\
\text { from student } \\
\text { involvement? }\end{array}$ & $\begin{array}{ll} & \text { Fresh views provided } \\
\text { - } & \text { Higher project profile on campus due to student exhibition and prize } \\
\text { giving by Vice Chancellor } \\
\text { - } & \text { Greater student ownership/care for the lake anticipated } \\
\text { - } & \text { Environmental awareness extended to teaching/learning } \\
\text { Collaboration between academics, administrative staff \& students } \\
\text { benefits all parties }\end{array}$ \\
\hline $\begin{array}{l}\text { What general benefits } \\
\text { could be anticipated } \\
\text { from student } \\
\text { involvement in CEAT } \\
\text { projects? }\end{array}$ & $\begin{array}{ll}\text { - } & \text { Student empowerment and leadership } \\
\text { - } & \text { Greater student awareness/respect for campus } \\
\text { - } & \text { May make project sponsorship easier thus implementation more likely } \\
\text { - } & \text { Enable students to liase with real clients }\end{array}$ \\
\hline $\begin{array}{l}\text { What general } \\
\text { disadvantages could } \\
\text { be anticipated from } \\
\text { student involvement in } \\
\text { CEAT projects? }\end{array}$ & 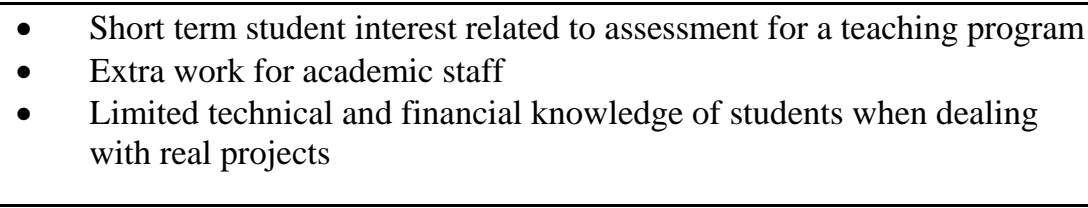 \\
\hline
\end{tabular}

Table $1 \quad$ Summary of responses from CEAT

Thirty percent of students responded to the questionnaire. It is noted that the students who responded were those students who had done well in the project. The questions and responses are summarized in Table 2. All student respondents indicated that they were now more aware of the natural environment on campus. They also indicated they were now more aware of the broader concept of sustainability and potential influence of architectural design on the environment. 
Karol, Dr Elizabeth (2006) Using campus concerns about sustainability as an educational opportunity: A case study in architectural design, Journal of Cleaner Production 14.

\begin{tabular}{|c|c|}
\hline QUESTION & SUMMARY OF RESPONSES \\
\hline $\begin{array}{l}\text { What was the } \\
\text { relevance of the lake } \\
\text { project to your } \\
\text { professional } \\
\text { development? }\end{array}$ & $\begin{array}{ll}\text { - } & \text { useful experience to present design to client } \\
\text { - } & \text { seeing the link between architectural design and landscape } \\
\text { - } & \text { understanding that all construction work has some impact on } \\
\text { - } & \text { sustainability } \\
\text { potential satisfaction of seeing design ideas implemented }\end{array}$ \\
\hline $\begin{array}{l}\text { What was the } \\
\text { relevance of the lake } \\
\text { project to you as a } \\
\text { campus user? }\end{array}$ & $\begin{array}{ll}\text { - } & \text { enhances knowledge of campus } \\
\text { - } & \text { encouraged viewing of campus with fresh eyes } \\
\text { - } & \text { not relevant if minimum time spent on campus }\end{array}$ \\
\hline $\begin{array}{l}\text { How do you perceive } \\
\text { the relationship } \\
\text { between existing } \\
\text { buildings on campus } \\
\text { and sustainability? }\end{array}$ & $\begin{array}{l}\text { - } \quad \text { outdoor places are treated as 'image enhancers' for adjoining buildings } \\
\text { rather than meeting specific needs for users over short and long term } \\
\text { - } \quad \text { buildings are not designed to meet even basic requirements of energy } \\
\text { efficiency } \\
\text { - } \quad \text { style seems to dictate choice of building materials and forms }\end{array}$ \\
\hline $\begin{array}{l}\text { Broadly what did you } \\
\text { learn from the project? }\end{array}$ & $\begin{array}{l}\text { - } \quad \text { clearer understanding of relationship between landscape and built form } \\
\text { - } \quad \text { some understanding of different disciplines that may contribute to } \\
\text { architectural design projects } \\
\text { - 'real world' projects are influenced by interest groups who may have } \\
\text { conflicting agendas }\end{array}$ \\
\hline
\end{tabular}

Table $2 \quad$ Summary of responses from students

\section{Discussion}

Three aspects of the case study are discussed in this paper. The first establishes the type of benefits realised if students are involved in campus sustainability initiatives, the second relates to the usefulness of the problem-based learning approach in increasing the awareness of architecture students to issues related to sustainability and the third considers the limitations of this ad hoc approach to sustainability education on this university campus.

The type of benefits accrued from involving students in projects related to sustainability appear to fall into two categories. One category is related to personal involvement of students with the notion of sustainability and the other category with the increased possibility of sustainability projects being implemented on a campus.

Students used terms such as 'enthusiasm', 'shared responsibility' and 'student empowerment' to capture the idea that when they invest time and energy in understanding an issue they are more likely to develop a commitment to that issue. They also hoped to make a difference towards resolving a real problem. A similar response was noted from a team of students involved in a feasibility study to improve the quality of storm water discharge from a parking area and a construction site at a Canadian university (Brunetti et al. 2003). This suggests that students who are involved in sustainable projects in their undergraduate studies are likely to carry with them a memory of the cross-disciplinary inputs required to address a problem in a sustainable manner.

Members of CEAT recognised that student involvement in a sustainable project may make a financial difference to that project. Student involvement may attract publicity and sponsorship. This could make the difference between a project proceeding or staying on the drawing board. CEAT members also saw a benefit to the image of CUT when sustainable projects were implemented. CUT would be perceived as an organisation that acknowledged its social responsibility when carrying out 
construction works. This position is taken by various universities in Australia (Walker-Morison, 2000; Crist, 2003) where it is recognised that any demonstrated commitment to sustainable projects can have a flow-on effect. The entire community is able to see how projects can be carried out to minimise impact on the environment whilst still providing high levels of amenity for people.

The results of the student survey suggest that, as established by Maitland (1997), architecture students are familiar with the problem-based learning approach to design. Problem-based learning also appears to be a useful tool to improve student understanding of the cross-disciplinary nature of sustainable design provided that appropriate experts are part of the teaching resource. These experts can identify environmentally sensitive issues relevant to a particular project. In the lake project a major area of sensitivity raised by an environmental biologist was the relationship between pedestrians and the frogs and turtles that had stopped breeding in the lake precinct. It was evident from the stronger design solutions that students were able to apply that specific knowledge into the design by separating sensitive animal habitats from pedestrians (refer to Figures 2 and 3).

However the weaker design solutions did not integrate the competing needs of people with the needs of local flora and fauna. These schemes either showed substantial buildings close to the lake or simply minimised pedestrian access. Neither approach satisfied the design brief.

There is an indication from responses to the question regarding students' learning outcomes, that there was insufficient traditional consultant support, particularly regarding costs and structural possibilities. Students indicated a reluctance to approach experts independently, thus additional formal presentations would have been desirable. However students seemed to recognize that non-traditional disciplines may need to be invited to contribute to the process of architectural design if a sustainable solution is to be achieved. An unexpected outcome was that students actually went to non-essential parts of the campus. One student even acknowledged that he did not realise there was a lake on campus.

Problem-based learning also requires students to develop general research skills and to be able to identify the specific discipline knowledge relevant to a particular project. For example in this project students were required to research the properties of materials suitable for outdoor use. In the light of their research, students were required to make an informed decision about the most appropriate materials for this project taking into account embodied energy, maintenance requirements and recycleability of the materials. Some students recognised that maintenance is a major consideration with campus construction. Others considered that embodied energy was the most important property to be considered when choosing materials, irrespective of the client. As an educational exercise it was pointed out that there is no single correct answer in terms of choice of materials to minimise environmental impact as the decision is coloured by a client's needs, wants, expectations and finances. However as indicated in the students' responses to assessing the relevance of the lake project to their professional development, a number of students did identify that they had become more conscious that all construction work has some impact on the environment. They were also more aware that the environmental response could be heavily influenced by various interest groups. 
It is suggested by Spellerberg et al. (2004) that universities adopting an ad hoc approach to sustainability cannot achieve a satisfactory environmental performance although some negative environmental impacts can be reduced. A minimum requirement for a tertiary institution to address sustainability should be an environmental policy together with sufficient resources to oversee implementation, monitoring and reporting of activities directed by the policy. This level of commitment would seem to be consistent with " a fundamental task of education [that] is to pass on knowledge and culture, which implies a belief in the future, and hence the need to safeguard the future" (Spellerberg et al. 2004, p. 128). CUT has not as yet recognized this position perhaps in part due to the funding pressures on universities in Australia particularly over the past five years.

\section{Conclusion}

This paper has shown that irrespective of administrative and governance practices, universities do provide an avenue for addressing matters related to sustainability, be it in an ad hoc manner. At grass roots level this can involve an action group on campus who try to raise awareness about environmental issues on campus. At the teaching/learning level this can manifest as problem-based learning projects set in a 'sustainable living' context on campus.

When an action group and students unite to work on the same project that incorporates sustainability, there appear to be benefits to all parties. Not only can the scope of a project be broadened as students bring various discipline specific perspectives to a problem but students' understanding and appreciation of their immediate surroundings is enriched as shown by student responses to this project. There may also be a greater possibility of sustainable projects being implemented on campus as a result of student involvement due to potential for positive publicity and financial sponsorship for projects.

Although no work on this particular project has yet been commissioned by the University, this approach of intertwining teaching projects with a 'sustainable living' attitude to the campus may yet bear fruit. It could provide a basis for increasing the pressure on this particular university to create policies that enable students to see the university as a leader in sustainable practices and provide strong learning experiences through action.

\section{References}

Brunetti, A., Petrell, R. and Sawada, B. (2003), “Team project-based learning enhances awareness of sustainability at the University of British Columbia, Canada”, International Journal of Sustainability in Higher Education, Vol. 4, No. 3, pp.210216. 
Carpenter, D. and Meehan, B. (2002), “Mainstreaming environmental management: Case studies from Australasian universities”, International Journal of Sustainability in Higher Education, Vol. 3, No. 1, pp.19-38.

Crist, G. (2003), “Monash Science Centre, Victoria”, BDP Environment Design Guide, Vol. CAS 32, RAIA, Melbourne.

Curtin University of Technology, (1993), “Annual Report Curtin University of Technology", CUT, Perth.

Curtin University of Technology (1994), "Mission, Vision and Values Statements" ,No. 10862-8-94, CUT, Perth.

Curtin University of Technology (2003), "Vision, Mission and Values statements", Retrieved: March 20, 2004, from http://official.curtin.edu.au/mission.html.

Davis, S., Edmister, J., Sullivan, K. and West, C. (2003), "Educating sustainable societies for the twenty-first century", International Journal of Sustainability in Higher Education, Vol. 3, No. 1, pp.169-179.

Engel, C. (1997), "Not just a method but a way of learning”. D. Boud \& G. Feletti (eds), The challenge of problem-based learning ( $2^{\text {nd }}$ ed.), Kogan Page, London pp.1727.

Leal Filho, W. (2000), "Dealing with misconceptions on the concept of sustainability”, International Journal of Sustainability in Higher Education, Vol. 1, No. 1, pp.9-17.

Maitland, B. (1997), "Problem based learning for architecture and construction management”.,D. Boud \& G. Feletti (Eds), The challenge of problem-based learning ( $2^{\text {nd }}$ ed.), Kogan Page, London p.211-217.

Spellerberg, I., Buchan, G. and Englefield, R. (2004), “Need a university adopt a formal environmental management system? Progress without an EMS at a small university”, International Journal of Sustainability in Higher Education, Vol. 5, No. 2, pp.125-132.

Walker-Morison, A. (2000), “A tale of two campuses: Charles Sturt University staff offices; Sunshine Coast University arts faculty building case study”, BDP Environment Design Guide, Vol. CAS 19, RAIA, Melbourne.

\footnotetext{
${ }^{\mathrm{i}}$ In spite of the lack of direction from management, in 2004 a sustainable development unit has been incorporated in all undergraduate chemical, mechanical, civil, electric and computer engineering programs and at the postgraduate level, a new sustainability management master's degree has been created.

${ }^{\text {ii }}$ CUT developed the Cleaner Production Action Plan under its obligations as Signatory Organisation to the Western Australian Cleaner Production Statement, administered by the Western Australian
} 
Sustainable Industry Group. The action plan can be viewed at

http://cleanerproduction.curtin.edu.au/sig/cpap/curtin.pdf. Commitments with regard to campus activities involved attempting to reduce paper waste on campus, minimising use of artificial light and electrical equipment and minimising and recycling waste from campus canteens.

iii The University Properties Office is the administrative section that manages the design, construction and operation of buildings and structures on campus.

${ }^{\text {iv }}$ Marcus Vitruvius Pollio, a Roman writer, architect and engineer, referred to three essential aspects of the built environment - firmness, commodity and delight, 'Delight' refers to an aesthetic value that gives pleasure to the user(Vitruvius, 1960). 